\title{
The Effect of Renewable Energy Consumption on Economic Growth in Croatia
}

\author{
Sonia Pearson*
}

\begin{abstract}
This paper investigates the effect of renewable energy on economic growth in Croatia for the period 1996-2018. The Autoregressive Distributed Lag (ARDL) technique is used to find the long run relationships between renewable energy, energy consumption and economic growth. The empirical analysis indicates that renewable energy has a positive and significant effect on economic growth in the short and long run. These findings indicate that the Croatian government can continue to boost renewable energy investment without impeding economic growth.
\end{abstract}

Keywords: Renewable energy; economic growth; ARDL; Croatia

JEL Classification: Q0, Q42, 013

\section{Introduction}

The Energy-Growth Nexus (EGN) literature investigates the causal relationship between energy consumption and economic growth (Hajko et al., 2018). The effects of global warming emerged as a key energy related policy topic following the oil shocks of the 1970s. Reducing carbon emissions has continued the discussion in the Energy-Growth Nexus (EGN) literature amid concerns of reduced economic growth due to climate mitigation policies. Decoupling energy use from emissions is the primary objective for the transition to renewable energy (RE). Although, $\mathrm{CO} 2$ emissions and economic growth have the greatest impact on RE consumption in high income countries (Omri \& Nguyen, 2014) social awareness of sustainability, climate change mitigation and $\mathrm{CO} 2$ reduction targets are not enough to motivate the switch from traditional renewable energy sources. Marques \& Fuinhas (2011) studied the commitment to RE sources on a set of 24 European countries and found that traditional

\footnotetext{
* Sonia Pearson is PhD Candidate at Faculty of Business and Economics, University of Zagreb, Trg J. F. Kennedy 6, HR-10000 Zagreb, Croatia, Tel: 0038595 5829342; Email: spearson@net.efzg.hr
} 
energy sources restrain deployment of renewables through lobbying. However once deployed renewable energy use has persistence. They also found that GDP and prices of fossil-based fuels were not significant for the development of renewables in the period from 1990 to 2006, suggesting that it was not the market that encouraged growth of the renewable industry.

The transition to a low carbon energy system faces a different scenario in Croatia. Croatia's existing hydroelectric plants and recent wind and solar power additions have enabled the country to exceed the EU's renewable energy target of 20 percent in final energy consumption by 2020, however, the country's energy intensity (EI) is 55 percent higher than the EU average. Adding more wind and solar power plants could help reduce Croatia's EI by replacing less efficient fuels such as coal, natural gas and biomass (in households) (The World Bank, 2018).

While it is apparent that energy supply plays a role in the economy, the question is whether EGN captures this relationship. Further, as energy decisions impact economic growth, the literature needs to take account of energy transition from conventional energy to renewable energy. Some researchers (Marques \& Fuinhas, 2018) make the case for studying the EGN nexus by disaggregating energy consumption by source. Therefore, this paper looks at the relationship between renewable energy (RE) and economic growth in Croatia.

\section{Energy-growth nexus}

The Energy-Growth Nexus (EGN) literature investigates the causal relationship between energy consumption and economic growth (Hajko et al., 2018). Following Jorgenson's introduction of an energy variable into Robert Solow's theory of economic growth (Kasperowicz et al., 2020), Kraft and Kraft's (1978) seminal paper on the causal relationship between energy and gross national product (GNP) identified unidirectional causality from GNP to energy. At the time, the relationship between gross energy consumption and gross national product was viewed as constant and unchanging. Therefore, energy conservation policies were considered unacceptable due to their adverse effect on economic activity. Kraft and Kraft's (1978) findings suggested that energy conservation policies would not impair economic growth. This was a significant observation following the period after the energy crises in the 1970s and the threat of reduced energy supply (Hajko et al., 2018). Research into the relevance of energy for economic growth continued, leading to four hypotheses on the relationship between energy consumption and economic growth; growth, conservation, feedback, and neutrality (Apergis \& Payne, 2012); with associated implications for energy policy.

The growth hypothesis is indicated by the presence of unidirectional causality from energy consumption to economic growth and implies that energy consump- 
tion impacts economic growth. Therefore, energy conservation policies will reduce energy consumption and impact economic growth. When this causality is reversed and unidirectional causality runs from economic growth to energy consumption, the inference is that energy consumption is dictated by economic growth. This relationship characterises the conservation hypothesis. In this situation, energy conservation policies do not have an adverse impact on economic growth. Bi-directional causality between energy consumption and economic growth indicates feedback and suggests an interdependent relationship. Here, energy conservation policies may impact economic growth. Finally, the absence of causality indicates the neutrality hypothesis where energy consumption has no impact on economic growth process. Here, energy conservation policies will also have no impact on economic growth.

As renewable energy technologies have become a key component of energy policy, the impact of renewable energy on economic growth has become an important debate in the EGN literature. Economic growth, energy consumption and environmental quality are generally viewed as conflicting interests in the short and medium run (Omri \& Nguyen, 2014). While increased RE deployment and its effect on economic growth has gained researchers' interests, the results have been mixed (Omri \& Nguyen, 2014). The variance in results has been attributed to differences in country characteristics.

Some researchers have found that economic growth has a positive effect on renewable energy consumption (Chang et al., 2009) (Sadorsky, 2009a) (Sadorsky, 2009b) (Irandoust, 2016). As incomes rise, concern for the environment grows leading to increased development in renewable energy and better environmental policies, regulations and institutions (Omri \& Nguyen, 2014) (Menegaki \& Tsagarakis, 2015).

However, different inputs in energy generation have different associated costs. Hydropower for example has relatively high fixed costs but low variable costs. These considerations lead to a mix of energy sources. Renewable energy is expensive compared to fossil fuel energy. Therefore, countries with large populations and energy intensive growth prefer traditional energy sources for economic reasons. The smallscale characteristics of solar PV have a positive effect on economic activity while wind power has a restrictive effect. Further, the expected substitution effect of RE has not been proven as they need to be backed up by fossil fuel. According to Marques \& Fuinhas (2018), this "backup load causes a negative effect on economic activity, due to the high economic inefficiencies in resources allocation which are associated with the idle capacity." Understanding the interactions of energy sources continues to attract researchers while disaggregating energy consumption by source has resulted provides a more reliable framework for policy making (Marques \& Fuinhas, 2018).

Chang et al (2009) studied OECD countries for the period from 1997 to 2006 and found that high economic growth has a positive effect on renewable energy. This effect was absent in countries with low economic growth. Similarly, Sadorsky (2009b) used panel co-integration to show that a $1 \%$ increase in GDP increased RE consump- 
tion by $3.5 \%$ in emerging economies. A separate study by Sadorsky (2009a) showed that GDP had a similar positive effect on renewable energy in the G7. Irandoust's (2016) study of the four Nordic countries also found unidirectional causality from growth to renewable energy. These findings were echoed in da Silva et al's, (2018) study of sub-Saharan Africa where economic growth was found to have a positive effect on renewable energy.

Ntanos et al's (2018) study of 25 European countries found a correlation between $\mathrm{RE}$ consumption and the economic growth of high income countries versus low income countries. Similarly, Kasperowicz et al (2020) studied 29 European countries and found a long-run relationship between economic growth and renewable energy consumption. However, they also found that renewable energy consumption has a positive impact on economic growth.

A bi-directional causal link between renewable energy and GDP in six emerging economies (Salim \& Rafiq, 2012) and the BRIC (Brazil, Russia, India, China) countries (Sebri \& Ben-Salha, 2014). Rafiq et al (2014) also found bidirectional causality in the long run in India while they found unidirectional causality from output to renewable energy in the long run in China.

Omri et al. (2015) found mixed results in their study on 17 developed and developing countries using simultaneous-equations panel data models. They found unidirectional causality from RE to economic growth in Hungary, India, Japan, the Netherlands and Sweden. Unidirectional causality from economic growth to renewable energy was found in Argentina, Spain and Switzerland. Finally, they found bidirectional causality in Belgium, Bulgaria, Canada, France, Pakistan and USA.

Ocal \& Aslan (2013) on the other hand found that renewable energy consumption has a negative impact on economic growth in Turkey and unidirectional causality runs from economic growth to renewable energy consumption. Dogan (2016) found unidirectional causality from RE to economic growth in the short run in Turkey but found a feedback effect in the long run. Dinc \& Akdogan (2019) also found bidirectional causality between renewable energy and economic growth in the short and long run in Turkey.

Thus, extant literature provides inconclusive results on the causal relationship between energy consumption and growth. The results of these studies are summarised in table 1 below. 
Table 1: Summary of renewable energy-economic growth papers

\begin{tabular}{|c|c|c|c|c|c|}
\hline Year & Authors & Period & Method & Region & Findings \\
\hline 2009 & $\begin{array}{l}\text { Chang, Huang } \\
\text { \& Lee }\end{array}$ & $1997-2006$ & $\begin{array}{l}\text { Panel } \\
\text { threshold } \\
\text { regression }\end{array}$ & OECD & $\begin{array}{l}\text { Countries with high economic growth } \\
\text { increase RE deployment. }\end{array}$ \\
\hline 2009 & Sadorsky & $1994-2003$ & $\begin{array}{l}\text { Panel } \\
\text { co-integration }\end{array}$ & $\begin{array}{l}18 \text { emerging } \\
\text { countries }\end{array}$ & $\begin{array}{l}\text { GDP growth has a positive impact on } \\
\text { RE deployment. }\end{array}$ \\
\hline 2009 & Sadorsky & $1920-2005$ & $\begin{array}{l}\text { Panel } \\
\text { co-integration }\end{array}$ & G7 & $\begin{array}{l}\text { GDP and CO2 emissions are major } \\
\text { drivers of RE deployment. }\end{array}$ \\
\hline 2012 & Salim \& Rafiq & 1980-2006 & $\begin{array}{l}\text { Panel data \& } \\
\text { time series }\end{array}$ & $\begin{array}{l}\text { Brazil, China, } \\
\text { India, Indonesia, } \\
\text { Philippines, } \\
\text { Turkey }\end{array}$ & $\begin{array}{l}\text { Bi-directional causality between } \\
\text { renewable energy and GDP in the short } \\
\text { run in six emerging economies }\end{array}$ \\
\hline 2013 & Ocal \& Aslan & $1990-2010$ & $\begin{array}{l}\text { ARDL, Toda- } \\
\text { Yamamoto } \\
\text { causality tests }\end{array}$ & Turkey & $\begin{array}{l}\text { Unidirectional causality from economic } \\
\text { growth to RE. }\end{array}$ \\
\hline 2014 & $\begin{array}{l}\text { Rafiq, Bloch \& } \\
\text { Salim }\end{array}$ & $1972-2011$ & $\begin{array}{l}\text { VECM, } \\
\text { Johansen } \\
\text { cointegration }\end{array}$ & India, China & $\begin{array}{l}\text { In India, bidirectional causality in the } \\
\text { long run while in China unidirectional } \\
\text { causality from GDP to RE. }\end{array}$ \\
\hline 2014 & Sebri \& Salha & $1971-2010$ & Panel ARDL & BRI & $\begin{array}{l}\text { Bidirectional relationship between RE } \\
\text { and economic growth. }\end{array}$ \\
\hline 2015 & $\begin{array}{l}\text { Omri, Ben } \\
\text { Mabrouk \& } \\
\text { Sassi-Tmar }\end{array}$ & 1990-2011 & Panel SEM & $\begin{array}{l}17 \text { developed } \\
\text { and developing } \\
\text { countries }\end{array}$ & $\begin{array}{l}\text { Unidirectional causality from economic } \\
\text { growth to RE in some countries, the } \\
\text { reverse in other countries and feedback } \\
\text { in the remaining countries. }\end{array}$ \\
\hline 2016 & Dogan & 1988-2012 & ARDL & Turkey & $\begin{array}{l}\text { Feedback between RE and economic } \\
\text { growth in the long and short run. }\end{array}$ \\
\hline 2016 & Irandoust & $1975-2012$ & VAR & Nordic countries & $\begin{array}{l}\text { Unidirectional causality from economic } \\
\text { growth to RE. }\end{array}$ \\
\hline 2018 & $\begin{array}{l}\text { Silva, Cerqueira } \\
\text { \& Ogbe } \\
\end{array}$ & 1990-2014 & Panel ARDL & SSA & $\begin{array}{l}\text { GDP and increased energy use have a } \\
\text { positive effect on RE. }\end{array}$ \\
\hline 2018 & Ntanos et al & $2007-2016$ & ARDL & Europe & $\begin{array}{l}\text { Correlation between RE and economic } \\
\text { growth in countries with higher GDP. }\end{array}$ \\
\hline 2019 & $\begin{array}{l}\text { Dinc \& } \\
\text { Akdogan } \\
\end{array}$ & $1980-2016$ & VECM & Turkey & $\begin{array}{l}\text { Bidirectional relationship between RE } \\
\text { and economic growth. }\end{array}$ \\
\hline 2020 & $\begin{array}{l}\text { Kasperowicz } \\
\text { et al }\end{array}$ & $1995-2016$ & $\begin{array}{l}\text { Panel } \\
\text { co-integration }\end{array}$ & $\begin{array}{l}29 \text { European } \\
\text { countries }\end{array}$ & $\begin{array}{l}\text { RE consumption has a positive impact } \\
\text { on economic growth }\end{array}$ \\
\hline
\end{tabular}

\section{Croatian energy consumption}

Croatian energy strategy has three main objectives: security of supply, competitiveness of the system and sustainability of energy development (Keček et al., 2019). Finland, Latvia and Sweden led the EU in 2019 as the largest consumers of renewable energy (see Figure 1). However, compared to other EU members, Croatia's use of re- 
newable electricity (including large-scale hydropower plants) is high and the country is currently ranked $6^{\text {th }}$ in the EU for renewable electricity use (Keček et al., 2019).

Since becoming a member of the European Union in 2013, the EU has a significant influence on Croatian energy policy. Croatia's domestic electricity consumption in 2016 was 17.7 terawatt hours (TWh) making it lower than before the financial crisis of 2007-2008 (The World Bank, 2018). The economy is moving away from energy-intensive industries like cement, chemical and metals to tourism, paper and printing and food. More than half of Croatia's electricity comes from hydro power. The rest comes from coal, gas and nuclear plants. During peak demand, over $40 \%$ of electricity is imported (The World Bank, 2018). Although significant progress has been made to increase competition in the electricity sector, competition is limited, and further market reforms are required (The World Bank, 2018). RE generation was supported through a feed-in tariff (FIT) system until 2015.

Figure 1: Share of renewable and bio-fuel energy in gross final energy consumption $-2019$

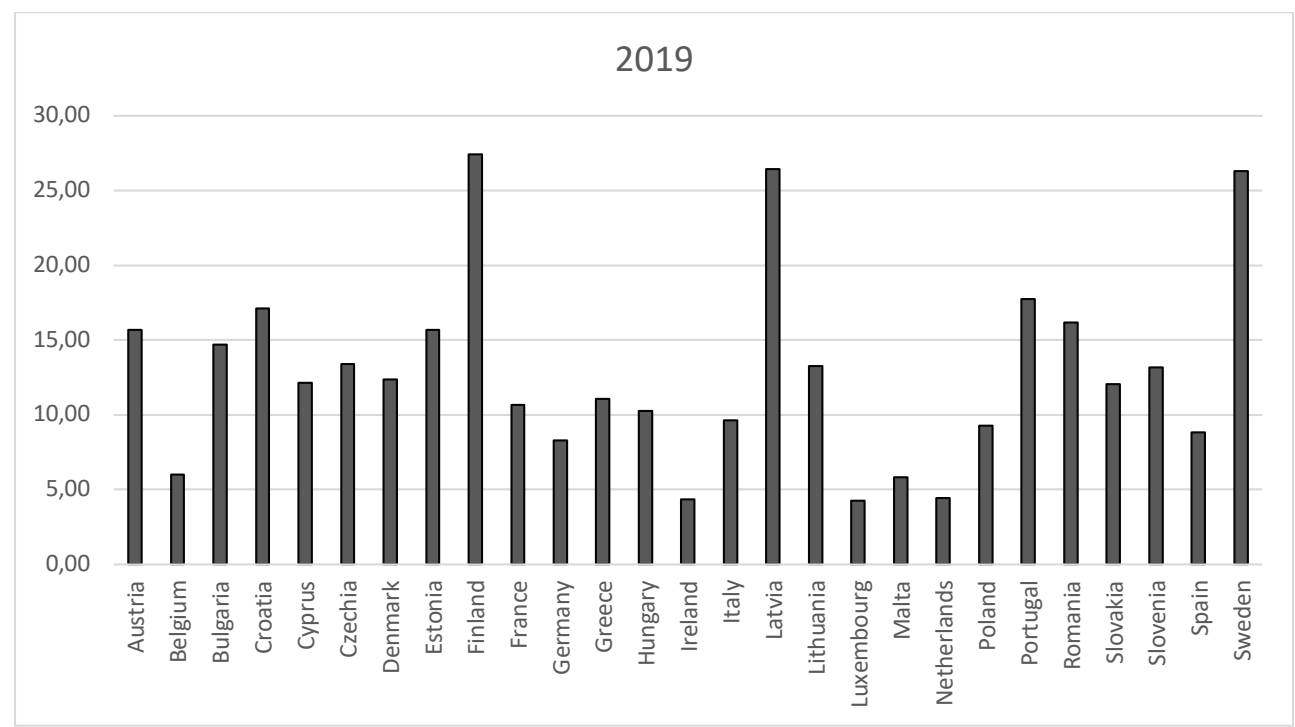

Data source: Eurostat

Final energy consumption in Croatia can be broken down as follows: $34.4 \%$ for the residential sector, $17.84 \%$ for the industrial sector, $12.21 \%$ for the commercial services sector, $32.03 \%$ for transportation and 3.52\% for other sectors (Eurostat, 2020). Energy intensity is higher than the EU28 average. Low efficiency biomass is the leading fuel in the residential sector and may be the cause of Croatia's high energy intensity. Unlike other European countries, Croatia spends more energy on cooling 
than heating. Estimates for Croatia's current demand for cooling stands at 1TWh but is predicted to double (The World Bank, 2018) and approach that of the United Kingdom's. Opportunities for increasing energy efficiency are vast as a large percentage of residential and commercial buildings have insufficient insulation.

Tourism, which is a vital sector of the Croatian economy, affects electricity usage. During the key months of July, August and September, the influx of tourists to the Croatian coast has a dramatic impact on electricity consumption. This strong seasonal aspect of the industry presents infrastructure and supply challenges. Solar power is ideally suited to meet such demand as electricity generation coincides with usage.

Energy independence is an ongoing debate in Croatia (Vlahinić-Dizdarević \& Žiković, 2010). Croatia's geographic location allows it to benefit from wind and solar power allowing it to balance day and night time intermittent energy (as sun shines during the day and wind blows at night) (Komušanac et al., 2016). Several studies have been done on the integration of RE (Dominković et al., 2016) (Cerovac, Ćosić, Pukšec, \& Duić, 2014) (Komušanac et al., 2016). These indicate that Croatia could get more than $75 \%$ of its energy from renewable sources by changing the energy system (Krajačić et al., 2011).

Other studies (Vlahinić-Dizdarević \& Žiković, 2010) (Jakovac, 2013) have found that economic growth has a positive effect on energy consumption suggesting the conservation hypothesis for the Croatian energy-growth relationship. This means energy system changes can be implemented without compromising economic growth and employment (Jakovac, 2013). However, some researchers have disputed the validity of the GDP data used in the study (Bićanić \& Tuda, 2014). Borozan (2013) on the other hand found that energy consumption contributes to GDP growth. However, further investigations revealed that the direction of causality between energy consumption and GDP depended on the individual energy form. The conservation hypothesis was confirmed for the relationship between GDP and liquid fuel, natural gas and hydropower whereas the findings for GDP and coal support the neutrality hypothesis (Borozan, 2013).

\section{Data and Methodology}

The aim of this paper is to understand the relationship between renewable energy and economic growth. The autoregressive distributed lag (ARDL) method or Bounds test has been identified as "one of the most flexible methods" in the econometric analysis of the EGN according to Menegaki (2019). This method tolerates different lags in different variables, regime shifts and shocks that characterise the commonly used variables used in energy studies. Further, the method provides unbiased estimates irrespective of endogeneity problems (Menegaki, 2019). Short and long run effects are estimated simultaneously. 
We first analyse the multivariate data for stationarity using a unit root test. Next a co-integration test is conducted using the Bounds test. If a cointegration equation(s) is present, the ARDL method is used to analyse the short and long-term relationships between the variables.

Following Dinc \& Akdogan (2019), economic growth is a function of renewable energy produced and energy consumed. The dependent variable in this study, GDP per capita in Euro for the period from 1996-2018, was downloaded from the Croatian Bureau of Statistics (2020). The two independent variables are gross inland energy consumed and renewable energy (biofuel, solar, wind) in gross inland consumption. As hydroelectric power is a mature technology, it has not been included in the renewable energy variable. Data was downloaded from Eurostat (2020) for the period 1996-2018.

Table 2: Variables

\begin{tabular}{|c|c|c|}
\hline Variable & Description & Source \\
\hline ENC & Gross inland consumption measured in TOE & \multirow[b]{2}{*}{ Eurostat } \\
\hline $\mathrm{RE}$ & $\begin{array}{l}\text { Renewable energy }+ \text { renewable electricity in Gross inland } \\
\text { consumption measured in tons of oil equivalent (TOE) }\end{array}$ & \\
\hline GDP & GDP per capita in Euro & Croatian Bureau of Statistics \\
\hline
\end{tabular}

Table 2 below presents the summary statistics. The mean renewable energy produced during the period of 1996-2018 is 2031.4 TOE with a standard deviation of 240.9 TOE. Mean GDP per capita for the same period is 8662.50 Euros with a standard deviation of 2631.90 Euros while gross inland energy consumption has a mean of 9043.3 TOE with a standard deviation of 592.42 TOE.

Table 3: Summary statistics

\begin{tabular}{|l|c|c|c|c|c|}
\hline Variable & Mean & Median & Std. Dev. & Min. & Max \\
\hline ENC & 9043.3 & 8880.1 & 592.42 & 8143.6 & 10158 \\
\hline RE & 2031.4 & 2011.5 & 240.9 & 1674.3 & 2518.8 \\
\hline GDP & 8662.5 & 10202 & 2631.9 & 4212.9 & 12615 \\
\hline
\end{tabular}

\section{Unit root test}

The first step of the ARDL method is unit root analysis to determine the degree of integration for each variable. The Augmented Dickey-Fuller (ADF) and Kwiakowski-Phillips-Schmid-Shin (KPSS) test was conducted all variables. The null hypothesis of the ADF test is that the variable is not stationary so the aim is to reject the null hypothesis which can be done if the p-value is below 0.05 at $5 \%$ significance. On the 
other hand, the null hypothesis of the KPSS test states that the series is stationary, so the objective is to fail to reject the null hypothesis. This can be done if the p-value is above 0.1. Table 3 presents the results of the ADF and KPSS unit root tests. The "D" used in front of the variables indicates the first difference. The order of integration I(1) indicates first differences transforms non-stationary variables to stationarity. The results of the ADF test, presented in table 3 below, indicate that GDP and RE are I(1) and thus fulfil the requirements for cointegration.

Table 4: Unit root test results

\begin{tabular}{|l|c|c|c|c|}
\hline Variable & ADF p-value & KPSS p-value & Test & Result \\
\hline GDP & 0.8344 & 0.036 & Constant & Not stationary \\
\hline D_GDP & 0.08574 & $>.10$ & Constant & Stationary \\
\hline RE & 0.9972 & 0.042 & Constant & Not stationary \\
\hline D_RE & 0.0005 & 0.058 & Constant & Stationary \\
\hline ENC & 0.0223 & $>.10$ & Constant & Stationary \\
\hline D_ENC & 0.124 & $>.10$ & Constant & Stationary \\
\hline
\end{tabular}

\section{ARDL}

The ARDL approach to cointegration involves testing for the existence of a longrun relationship between the variables. This is done by computing the F-statistic for testing the significance of the lagged levels of the variables in the error correction form of the underlying ARDL model (Pesaran \& Pesaran, 2009). Table 4 presents the results of the bounds test based on the SBC criteria. The computed F-statistic of 0.7271 is below the lower bound at the $95 \%$ significance level indicating the existence of a long-run relationship between the variables irrespective of the order of integration.

Model: $G D P=f(R E, E N C)$

Table 5. Summary of ARDL bounds test

\begin{tabular}{|l|c|c|c|c|}
\hline F-stat & 95\% lower bound & 95\% upper bound & $\mathbf{9 0 \%}$ lower bound & 90\% upper bound \\
\hline 0.7271 & 4.6288 & 5.9727 & 3.6258 & 4.8075 \\
\hline W-stat & & & & \\
\hline 2.1812 & 13.8863 & 17.9181 & 10.8775 & 14.4224 \\
\hline
\end{tabular}

The ARDL $(1,2,0)$ long-run model based on SBC criteria can now be estimated. The results indicate a positive relationship between GDP, RE and ENC in the long run. Increases in RE and ENC lead to an increase in GDP. T-ratios indicate that RE 
is a significant factor in determining GDP and all the coefficients are statistically significant. Table 5 presents the results.

Table 6: Estimated long-run coefficients of GDP

\begin{tabular}{|l|c|c|c|c|}
\hline Variable & Coefficient & Std. Error & T-Ratio & Probability \\
\hline RE & 11.8416 & 2.1924 & 5.4011 & 0.000 \\
\hline ENC & 2.8854 & 0.9032 & 3.1948 & 0.006 \\
\hline INPT & -39468.8 & 10769.7 & -3.6648 & 0.003 \\
\hline
\end{tabular}

The error correction model associated with these long-run estimates are presented in Table 6. Apart from the coefficient of dRE, all other coefficients are statistically significant. The error correction coefficient estimated at -0.2152 is statistically highly significant, has the correct sign and suggests a moderate speed of convergence to equilibrium. Almost $22 \%$ of the disequilibria of the previous year's shock adjusts back to the long-run equilibrium in the current year. A positive change in the current lag of RE has a positive but statistically insignificant change on GDP. On the other hand, a positive change in the current lag of ENC has a positive and significant effect on GDP.

The robustness of the model is confirmed by diagnostics tests. The null hypothesis of the Lagrange multiplier test of residual serial correlation states that there is no serial correlation in the residuals up to the specified order. Results of Ramsey's Reset test, normality and heteroscedasticity test, presented in table 7 below, suggest that the model is adequately estimated and that the conclusions of the model are acceptable.

Table 7: Estimated Error Correction representation of the ARDL model

\begin{tabular}{|l|c|c|c|c|}
\hline Variable & Coefficient & Std. Error & T-Ratio & Probability \\
\hline dRE & 0.6016 & 0.7332 & 0.8206 & 0.425 \\
\hline dRE_1 & -1.7946 & 0.6965 & -2.5765 & 0.021 \\
\hline dENC & 0.6210 & 0.2161 & 2.8739 & 0.012 \\
\hline ecm $(-1)$ & -0.2152 & 0.0838 & -2.5681 & 0.021 \\
\hline
\end{tabular}

Table 8: Diagnostic tests of the ARDL model

\begin{tabular}{|l|c|c|c|c|}
\hline Test & LM version & Probability & Fversion & Probability \\
\hline Serial correlation & 0.0100 & 0.920 & 0.0065 & 0.937 \\
\hline Ramsey's RESET & 0.2321 & 0.630 & 0.1526 & 0.702 \\
\hline Normality & 1.1357 & 0.567 & - & 0.380 \\
\hline Heteroscedasticity & 0.86219 & 0.353 & 0.81093 & \\
\hline
\end{tabular}




\section{Results}

The results of the analysis show that renewable energy has a positive effect on GDP. Furthermore, the impact is significant in the short and long run i.e. an increase in RE consumption has a positive impact on GDP in the short and long run. These results are consistent with the results of existing studies (Bhattacharya, Paramati, Ozturk, \& Bhattacharya, 2016) (Ntanos et al., 2018) (Kasperowicz et al., 2020) that show the positive effect of RE in countries such as Austria, Bulgaria, Canada, Chile, China, the Czech Republic, Denmark, Finland, France, Germany, Greece, Italy, Kenya, Republic of Korea, Morocco, the Netherlands, Norway, Peru, Poland, Portugal, Romania, Spain and the United Kingdom.

Further the negative and statistically significant coefficient of the lagged error correction term validates the existence of a long run relationship between GDP, RE and ENC. The coefficient implies that deviations from the long run equilibrium are corrected by almost $22 \%$ in each year.

\section{Conclusion and policy implication}

The environmental and economic threats posed by fossil fuels has necessitated the need for a transition to renewable energy sources. The adoption of the Kyoto Protocol which came into force in 2005 called for the reduction of greenhouse gas emissions necessitating the decoupling of emissions from energy use. The EGN literature examines the links between economic growth and energy consumption. Although this link has been studied in several regions and countries around the world, few studies exist for the Croatian economy and fewer still exist for energy consumption by source. As the newest member of the EU, Croatia has the potential to reduce its carbon intensity and promote sustainable development by utilising its vast RE potential. However, previous studies have hinted at the damaging effects of increased renewable energy on economic growth. Therefore, the main objective of this study is to examine the impact of RE on economic growth in Croatia.

Using the ARDL method, this paper established that renewable energy consumption has a positive effect on the Croatian economy. This is an encouraging result as Croatia's climate and geography make it ideal for RE production. Distributed generation of RE is ideal for the large number of Croatian islands which depend on tourism and have high cooling needs. Further as an energy dependent country, by diversifying its energy mix, Croatia reduces its vulnerability to oil price volatility. RE consumption levels in Croatia have been largely consistent since 1996 possibly due to Croatia's large hydroelectric capacity. The results imply that Croatian policy makers should continue promoting renewable energy investment particularly as tourists 
become more environmentally conscious and the EU implements its plan for energy efficient industrialisation.

The integration of the EU energy market would provide opportunities for the supply of renewable energy to other EU states while helping the EU achieve its objective of carbon neutrality by 2050 . Croatia has ample RE potential and can easily supply RE to EU countries with lower RE potential, while consuming hydroelectric power for itself. The Croatian government should also promote energy efficiency measures and continue developing human expertise. Feed-in tariffs, tax or credit incentives and sales tax exemptions for solar cells can all help foster the development of renewable energy.

This study has several limitations. Firstly, in the interest of parsimony, it does not account for all the variables that affect economic growth. Secondly, it does not account for structural breaks that may affect the data. Future research would do to take both into account.

\section{REFERENCES}

A. Kraft; J. Kraft. (1978). On the relationship between energy and GNP. The Journal of Energy and Development, 3, 401-403.

Apergis, N., \& Payne, J. E. (2012). Renewable and non-renewable energy consumption-growth nexus: Evidence from a panel error correction model. Energy Economics, 34(3), 733-738. https:// doi.org/10.1016/j.eneco.2011.04.007

Bhattacharya, M., Paramati, S. R., Ozturk, I., \& Bhattacharya, S. (2016). The effect of renewable energy consumption on economic growth: Evidence from top 38 countries. Applied Energy, 162, 733-741. https://doi.org/10.1016/j.apenergy.2015.10.104

Bićanić, I., \& Tuda, D. (2014). Long-term time series of GDP in Croatia. Privredna Kretanja i Ekonomska Politika, 23(134), 37-69.

Borozan, D. (2013). Exploring the relationship between energy consumption and GDP: Evidence from Croatia. Energy Policy, 59, 373-381. https://doi.org/10.1016/j.enpol.2013.03.061

Cerovac, T., Ćosić, B., Pukšec, T., \& Duić, N. (2014). Wind energy integration into future energy systems based on conventional plants - The case study of Croatia. Applied Energy, 135, 643-655. https://doi.org/10.1016/j.apenergy.2014.06.055

Chang, T. H., Huang, C. M., \& Lee, M. C. (2009). Threshold effect of the economic growth rate on the renewable energy development from a change in energy price: Evidence from OECD countries. Energy Policy, 37(12), 5796-5802. https://doi.org/10.1016/j.enpol.2009.08.049

Croatian Bureau of Statistics. (2020). GDP Annual Calculation.

da Silva, P. P., Cerqueira, P. A., \& Ogbe, W. (2018). Determinants of renewable energy growth in Sub-Saharan Africa: Evidence from panel ARDL. Energy, 156, 45-54. https://doi.org/10.1016/j.energy.2018.05.068

Dinç, D. T., \& Akdoğan, E. C. (2019). Renewable energy production, energy consumption and sustainable economic growth in Turkey: A VECM approach. Sustainability, 11(5). https://doi. org/10.3390/su11051273

Dogan, E. (2016). Analyzing the linkage between renewable and non-renewable energy consumption and economic growth by considering structural break in time-series data. Renewable Energy, 99, 1126-1136. https://doi.org/10.1016/j.renene.2016.07.078 
Dominković, D. F., Bačeković, I., Ćosić, B., Krajačić, G., Pukšec, T., Duić, N., \& Markovska, N. (2016). Zero carbon energy system of South East Europe in 2050. Applied Energy, 184, 1517-1528. https://doi.org/10.1016/j.apenergy.2016.03.046

Eurostat. (2020). Croatia Energy Balances. Retrieved November 15, 2020, from https://ec.europa.eu/ eurostat/web/main/data/database

Hajko, V., Sebri, M., Al-Saidi, M., \& Balsalobre-Lorente, D. (2018). The Energy-Growth Nexus: History, Development, and New Challenges. In The Economics and Econometrics of the Energy-Growth Nexus (pp. 1-46). Elsevier. https://doi.org/10.1016/B978-0-12-812746-9.00001-8

Irandoust, M. (2016). The renewable energy-growth nexus with carbon emissions and technological innovation: Evidence from the Nordic countries. Ecological Indicators, 69, 118-125. https:// doi.org/10.1016/j.ecolind.2016.03.051

Jakovac, P. (2013). Empirical Analysis on Economic Growth and Energy Consumption Relationship in Croatia1. Economic Research-Ekonomska Istraživanja, 26(4), 21-42. https://doi.org/10.1080 /1331677X.2013.11517628

Kasperowicz, R., Bilan, Y., \& Štreimikienė, D. (2020). The renewable energy and economic growth nexus in European countries. Sustainable Development, (March), 1-8. https://doi.org/10.1002/ sd. 2060

Keček, D., Mikulić, D., \& Lovrinčević, Ž. (2019). Deployment of renewable energy: Economic effects on the Croatian economy. Energy Policy, 126(November 2018), 402-410. https://doi. org/10.1016/j.enpol.2018.11.028

Komušanac, I., Ćosić, B., \& Duić, N. (2016). Impact of high penetration of wind and solar PV generation on the country power system load: The case study of Croatia. Applied Energy, 184, 1470-1482. https://doi.org/10.1016/j.apenergy.2016.06.099

Krajačić, G., Duić, N., Zmijarević, Z., Mathiesen, B. V., Vučinić, A. A., \& Da Graa Carvalho, M. (2011). Planning for a $100 \%$ independent energy system based on smart energy storage for integration of renewables and CO2 emissions reduction. Applied Thermal Engineering, 31(13), 2073-2083. https://doi.org/10.1016/j.applthermaleng.2011.03.014

Marques, Antonio C, \& Fuinhas, J. A. (2018). On the Dynamics of Renewable Energy Consumption (Aggregated and Disaggregated) and Economic Growth: An Approach by Energy Sources. In The Economics and Econometrics of the Energy-Growth Nexus (pp. 77-112). Elsevier. https://doi.org/10.1016/B978-0-12-812746-9.00003-1

Marques, António Cardoso, \& Fuinhas, J. A. (2011). Drivers promoting renewable energy: A dynamic panel approach. Renewable and Sustainable Energy Reviews, 15(3), 1601-1608. https://doi. org/10.1016/j.rser.2010.11.048

Menegaki, A. N. (2019). The ARDL method in the energy-growth nexus field; best implementation strategies. Economies, 7(4), 1-16. https://doi.org/10.3390/economies7040105

Menegaki, A. N., \& Tsagarakis, K. P. (2015). Rich enough to go renewable, but too early to leave fossil energy? Renewable and Sustainable Energy Reviews. https://doi.org/10.1016/j. rser.2014.09.038

Ntanos, S., Skordoulis, M., Kyriakopoulos, G., Arabatzis, G., Chalikias, M., Galatsidas, S., ... Katsarou, A. (2018). Renewable energy and economic growth: Evidence from European countries. Sustainability (Switzerland), 10(8), 1-13. https://doi.org/10.3390/su10082626

Ocal, O., \& Aslan, A. (2013). Renewable energy consumption-economic growth nexus in Turkey. Renewable and Sustainable Energy Reviews, 28, 494-499. https://doi.org/10.1016/j. rser.2013.08.036

Omri, A., Ben Mabrouk, N., \& Sassi-Tmar, A. (2015). Modeling the causal linkages between nuclear energy, renewable energy and economic growth in developed and developing countries. Renewable and Sustainable Energy Reviews, 42, 1012-1022. https://doi.org/10.1016/j. rser.2014.10.046 
Omri, A., \& Nguyen, D. K. (2014). On the determinants of renewable energy consumption: International evidence. Energy, 72(SEPTEMBER 2014), 554-560. https://doi.org/10.1016/j.energy.2014.05.081

Pesaran, B., \& Pesaran, M. H. (2009). Time series econometrics: using Microfit 5.0.

Rafiq, S., Bloch, H., \& Salim, R. (2014). Determinants of renewable energy adoption in China and India: a comparative analysis. Applied Economics, 46(22), 2700-2710. https://doi.org/10.108 0/00036846.2014.909577

Sadorsky, P. (2009a). Renewable energy consumption, CO2 emissions and oil prices in the G7 countries. Energy Economics, 31(3), 456-462. https://doi.org/10.1016/j.eneco.2008.12.010

Sadorsky, P. (2009b). Renewable energy consumption and income in emerging economies. Energy Policy, 37(10), 4021-4028. https://doi.org/10.1016/j.enpol.2009.05.003

Salim, R. A., \& Rafiq, S. (2012). Why do some emerging economies proactively accelerate the adoption of renewable energy? Energy Economics, 34(4), 1051-1057. https://doi.org/10.1016/j.eneco.2011.08.015

Sebri, M., \& Ben-Salha, O. (2014). On the causal dynamics between economic growth, renewable energy consumption, $\mathrm{CO} 2$ emissions and trade openness: Fresh evidence from BRICS countries. Renewable and Sustainable Energy Reviews, 39(52535), 14-23. https://doi.org/10.1016/j. rser.2014.07.033

The World Bank. (2018). Croatia Energy Sector Note. https://doi.org/10.1596/978-0-8213-9968-2

Vlahinić-Dizdarević, N., \& Žiković, S. (2010). The Role of Energy in Economic Growth: the case of Croatia. Proceedings of Rijeka Faculty of Economics - Journal of Economics and Business, 28, 35-60. Retrieved from https://hrcak.srce.hr/54096 